\title{
Entrepreneurship: One Key To Integrated Business Education
}

\author{
Matthew L. O’Connor (E-mail: matthew.oconnor@quinnipiac.edu), Quinnipiac University \\ Dale W. Jasinski (E-mail: dale.jasinski@quinnipiac.edu), Quinnipiac University \\ Chad Nehrt (E-mail: chad.nehrt@quinnipiac.edu), Quinnipiac University \\ Kathleen Simione (E-mail: kathleen.simione@quinnipiac.edu), Quinnipiac University
}

\begin{abstract}
This paper presents a case study of the key issues in implementing an innovative approach to teaching the business core curriculum. The program utilizes entrepreneurship as a key integrating theme and is designed to include two major active learning components: the development of a business plan and the implementation of a student business. The course integrates crossfunctional topic areas including accounting, finance, international business, management, and marketing. The paper describes the program in detail and identifies the key challenges and opportunities that remain. From the student and faculty feedback it appears obvious that while certain improvements need to made and institutional resources increased, the course offers a unique educational experience.
\end{abstract}

\section{Introduction}

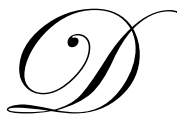

uring the 1990's the Association to Advance Collegiate Schools of Business (AACSB) formally recognized the need to better integrate business school curricula. Several schools have responded with new or revised courses, but the goal of a viable integrated business curriculum remains elusive. At the same time, the benefits from increasing the active learning components of the curriculum (Bradford and Peck, 1997) are gaining acceptance. Finally, the field of entrepreneurship has emerged as an important business discipline in its own right. A quick glance through course catalogs confirms that most business schools offer at least one course in entrepreneurship. Many offer minors or full majors in the topic. Indeed, reputations of certain schools have been built on the basis of an entrepreneurially-focused curriculum. Yet, the role of entrepreneurship in an integrated, active learning business core has received little attention.

This paper presents a case study that examines an innovative model for teaching the business core disciplines as an integrated approach to entrepreneurship. The program, entitled Adventures in Entrepreneurship, is designed to provide an active learning environment using a faculty team comprising subject matter experts from the core business disciplines. Students in the program earn 18 core business credits in a two semester sequence. The paper describes the program as well as the opportunities and challenges encountered by the faculty, students, and the university since its inception three years ago. An overview of program assessment is also included.

This case study occurs at a school of business that is accredited by the AACSB and has an enrollment of approximately 1,200 undergraduate students, 300 graduate students and 55 full time faculty. The entire university has an enrollment of about 5,000 undergraduate and 1,000 graduate students. The university focuses on traditional 18-22 year old college students, and about two thirds of undergraduates live on campus. The business school offers Bachelor of Science degrees in accounting, advertising, computer information systems, entrepreneurship and small business management, finance, international business, management, and marketing, and Masters degrees in business administration, accounting, and computer information systems. 


\section{Motivating Factors}

In the spring of 2000, the school of business completed an 18-month review of its core business curriculum. The review determined the core required greater pedagogical emphasis on active learning and cross-functional integration. Based on this review, the school established a five member team to design a new core curriculum. Their main charge was to design and implement an integrated model for teaching core business topics (Managerial Accounting, Marketing Principles, Fundamentals of Finance, International Business, Process of Management and Management \& Human Behavior). A secondary charge was to provide students with increased opportunities for active learning. Before discussing the program design and outcomes, we review the pedagogical motivations for these charges.

\subsection{Traditional Approaches To The Business Core Curriculum}

Business schools have traditionally delivered core concepts through stand-alone courses. Critics suggest that this leaves students with little understanding of the interrelationships between business disciplines (DeMoranville, et al., 2000; and Behrman and Levin, 1984). In addition, students have difficulty applying tools learned in one field to issues arising in other fields. For example accounting, finance, marketing and management all consider break-even analysis an important skill. However, students often see this singular tool as four different skills instead of one tool applicable to many different situations (Unpublished Core Curriculum Committee Report, 2000). These concerns are not new. For example, Porter and McKibbin (1988) call for cross-functional integration of the business curriculum. As noted earlier, the AACSB has also recognized the need to integrate business disciplines. More recently, LeClair (1998) and McKinney (1998) agree that integration of core business concepts will be vital to students entering $21^{\text {st }}$ century organizations. Barker, et al. (1998) suggests that business executives believe that students need greater team-oriented skills, and an improved cross/functional, interdisciplinary perspective. In response to these criticisms, some schools have begun to integrate their core curricula. For example, Aurand et al. (2001), Barber, et al. (2001), Luse (1999), Michaelsen (1999) and Pharr, et al. (1998) describe various approaches to implementing an integrated business core curriculum. However, none seem to be as focused on entrepreneurially oriented, active learning elements as Adventures in Entrepreneurship.

\subsection{Traditional Approaches To Curriculum Delivery}

Traditional core business classes are structured primarily around lectures, homework review, and examinations. With regard to student learning outcomes, this approach may not always be the most successful. O'Sullivan and Cooper (2003) suggest that an active learning framework, requiring students to formulate their own ideas, draw conclusions from experimental evidence, and participate in other similar activities, is more effective. Likewise, Weinstein (1996) suggests that, "Students must take an active role in converting new information into meaningful knowledge."

\subsection{Why Entrepreneurship?}

Interestingly, entrepreneurship was not originally considered as a major component of Adventures in Entrepreneurship. Nevertheless, introductory entrepreneurship classes emphasize the application of skills from most if not all of the core disciplines to the development of a business plan. Hence, the standard pedagogical model in entrepreneurship is built on an integrated, cross-functional platform. An understanding of this model led the faculty team to embrace entrepreneurship as the primary course theme. The faculty team also embraced the development of the business plan as a unique active learning element. More importantly, the team decided to organize and introduce topic areas in conjunction with students' development of their business plans. As the program evolved, the design team further extended the active learning components by requiring the class to implement and run one of the student business plans. In effect, business planning and implementation became the primary organizational vehicles around which the program was built and core business concepts were introduced.

Exhibit 1 diagrams the placement of a typical core business principles class, an entrepreneurship business planning course, and the Adventures in Entrepreneurship program on a subject depth versus integration plane. 
Isolated principles courses concentrate on a single functional area and treat that area in greater depth than a business planning course, but students have difficulty seeing how functional areas relate. Hence they plot in the upper left quadrant. The typical entrepreneurship business planning course links functional topics together through the planning process. However, instructors lack the expertise and time to delve too deeply into a single topic area. As a result, it lies in the lower right hand quadrant. We believe that Adventures in Entrepreneurship provides a healthy dose of cross-functional integration while retaining much of the subject matter depth associated with traditional principles courses. Hence, its placement in the upper right hand quadrant.

Exhibit 1

Subject Matter Depth vs. Integration

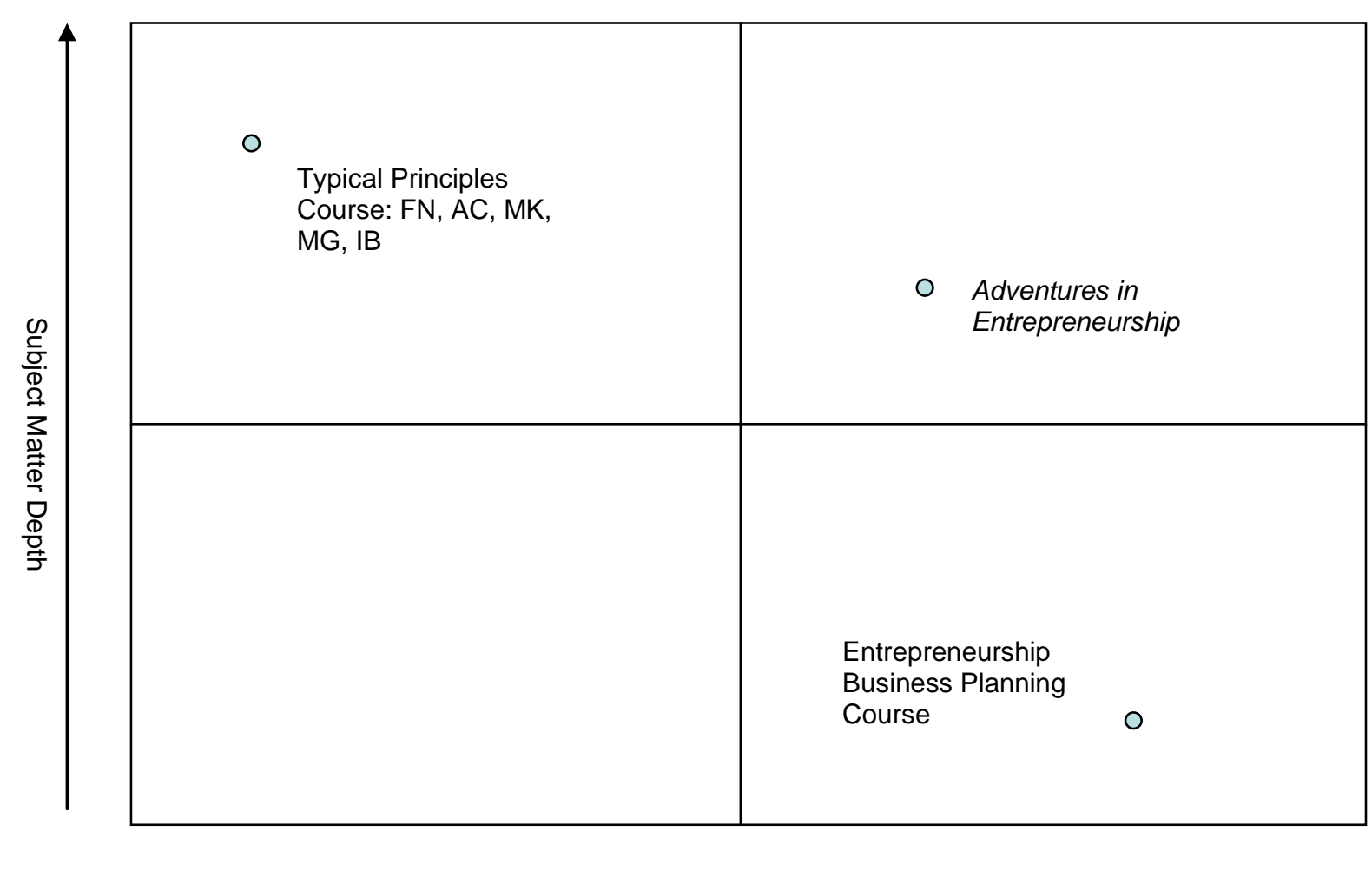

Degree of Cross-Disciplinary Integration

$\mathrm{FN}=$ Fundamentals of Finance $; \mathrm{AC}=$ Managerial Accounting; $\mathrm{MK}=$ Marketing Principles;

MG = Process of Management/Management \& Human Behavior; IB = International Business

\section{Program Overview}

\subsection{Structure Of The Program}

Adventures in Entrepreneurship is a two semester program in which students earn nine core credit hours per semester. Six credit hours per semester are classroom based. Students earn an additional three credits per semester in practicums designed as team based, active learning program elements. The fall semester practicum is devoted to the development of a business plan for a campus-based student business. Exhibit 2 presents the required components and associated grading weights for the business plan. At the end of the fall semester the class meets and, with faculty oversight, selects one plan to implement during spring semester. The spring semester practicum 
requires the class to implement the selected business plan. Each practicum requires students to evaluate their teammates' contributions. Exhibit 3 presents a team evaluation form. Essentially, the form allows each student to award points to their teammates based on meeting attendance, participation, completed work assignments, timeliness of work assignments, and enthusiasm. Points awarded by teammates become part of a students' practicum grade. This gives teams a tool to deal with free riders. The six hours of classroom instruction each semester comprise lectures, speakers, discussions, workshops, and problem sessions. As discussed below, classroom instruction presents the topics from a typical principles class, but in an order designed to support the needs of the practicum. Throughout the year, students are evaluated on their business plans, the success of their business operation, and on core concepts from the functional areas. Hence, students are evaluated on both individual and group/team assignments. A field trip to an entrepreneurial company is also part of the program.

Exhibit 2

Business Plan Requirements And Grading

\begin{tabular}{|c|c|c|}
\hline \multicolumn{3}{|c|}{$\begin{array}{l}\text { The business plan is completed as a team project and is evaluated for both the quality and completeness of the written and oral } \\
\text { presentation. It constitutes the grade for the practicum portion of the fall semester. Accordingly, this is a very important } \\
\text { project and you need to invest a significant portion of time and effort to do well. In order to assist you in understanding the } \\
\text { evaluation process, the following grading guidelines will be used by the faculty. }\end{array}$} \\
\hline Section & Topics & $\begin{array}{l}\text { Grading } \\
\text { Weights }\end{array}$ \\
\hline Executive summary & $\begin{array}{l}\text { Summary of plan } \\
\text { Highlights of each major section } \\
\text { Critical risks and responses }\end{array}$ & $10 \%$ \\
\hline Management & $\begin{array}{l}\text { Industry analysis } \\
\text { Strategy } \\
\text { Organizational chart and plan } \\
\text { Management team } \\
\text { Production strategy } \\
\text { Exit strategy }\end{array}$ & $30 \%$ \\
\hline Accounting & $\begin{array}{l}\text { Detailed Cost of Product Analysis } \\
\text { Detailed Schedule of Expenses } \\
\text { Break-Even Analysis }\end{array}$ & $15 \%$ \\
\hline Finance & $\begin{array}{l}\text { One Period Pro Forma Statement of Cash Flows } \\
\text { One Period Pro Forma Income Statement } \\
\text { One Period Pro Forma Balance Sheet }\end{array}$ & $15 \%$ \\
\hline Marketing & $\begin{array}{l}\text { Product Idea } \\
\text { Market Segmentation \& Target Market } \\
\text { Distribution Strategy } \\
\text { Pricing \& Promotion Strategy }\end{array}$ & $15 \%$ \\
\hline International Business & Potential International Business Opportunities Plus Country Assessment & $15 \%$ \\
\hline TOTAL Points & & $100 \%$ \\
\hline
\end{tabular}

\subsection{Topic Sequencing And Skills Development}

Course elements are introduced in the order in which students need them for the business plan or its implementation phase. For example, product ideas need to be developed early in the first semester. The marketing professor introduces the appropriate theory and concepts. The management professor joins in with brainstorming and creativity exercises. Once product ideas are gelling, some marketing research needs to be conducted. Eventually, sales targets are established. This motivates the need for operational plans and a management structure to be developed. Operational plans need budgets, so the managerial accounting component of the course begins. Eventually pro forma financial statements need to be developed and analyzed. The students move from accounting to finance. Students need to think about the eventual internationalization of their business, so the international business professor steps in. 
[Insert Exhibit 3 About Here]

Exhibit 3

Team Evaluation Form

(type in your name)

\begin{tabular}{|c|c|c|c|c|c|c|}
\hline & Evaluatee \#1 & Evaluatee \#2 & Evaluatee \#3 & Evaluatee \#4 & Evaluatee \#5 & YOURSELF \\
\hline Evaluation item & $\begin{array}{l}\text { Type in team } \\
\text { member name }\end{array}$ & $\begin{array}{l}\text { Type in team } \\
\text { member name }\end{array}$ & $\begin{array}{l}\text { Type in team } \\
\text { member name }\end{array}$ & $\begin{array}{l}\text { Type in team } \\
\text { member name }\end{array}$ & $\begin{array}{l}\text { Type in team } \\
\text { member name }\end{array}$ & $\begin{array}{c}\text { Type in } \\
\text { your name }\end{array}$ \\
\hline Prompt in attendance at team meetings. & & & & & & \\
\hline $\begin{array}{l}\text { Delivered agreed-upon parts of project in a } \\
\text { complete fashion }\end{array}$ & & & & & & \\
\hline Met deadlines. & & & & & & \\
\hline $\begin{array}{l}\text { Volunteered appropriately during team meet- } \\
\text { ings when tasks need to be accomplished. }\end{array}$ & & & & & & \\
\hline $\begin{array}{l}\text { Pulled fair share with regard to overall work- } \\
\text { load. }\end{array}$ & & & & & & \\
\hline $\begin{array}{l}\text { Showed enthusiastic and positive attitude abc } \\
\text { team activities and fellow team members }\end{array}$ & & & & & & \\
\hline $\begin{array}{l}\text { Based on the points available for the team, I } \\
\text { would "pay" this person } \\
\text { share of the team points. *See note below }\end{array}$ & & & & & & \\
\hline
\end{tabular}

The last row asks you to "pay" your team members by distributing a set number of points among team members. For example, a 4-member team has 400 points and a 5-member team has 500 points. Include the points awarded to yourself in the bottom right cell.

Note: This document was developed by the Quinnipiac University School of Business SB100 Teaching Team. Students have used this form or a modified version of this form in the freshman level class, SB100 The Business Environment. 
At each step, the students have a practical outcome (another component of the business plan) they need to produce. The skills to produce that outcome are covered in class. Before introducing skills, the foundational theory or concepts supporting the skills are covered. The process gives faculty the chance to design lectures and assignments that bridge the gap from one discipline to another. For example, the operational plan (management) leads to a budgeting process (accounting) which in turn influences the pro forma financial statements (finance). From the student perspective, topics are introduced in a practical order and reinforced with active, outcome oriented exercises. Because the business plan is theirs, students are better able to own the material.

A pedagogical advantage to the program is that common business skills can be introduced once and applied in many different scenarios. A good example is break-even analysis. In a traditional business core students are exposed to cost-volume-profit (CVP) analysis and operating leverage in Managerial Accounting. They see operating leverage, financial leverage, and project break-even analysis in their Fundamentals of Finance course. Their Process of Management course likely incorporates break-even tools in discussions about the trade-offs between labor and capital, and finally the Marketing Principles instructor revisits the concept in discussions about product break-even. Hence in the traditional business core, students are exposed to the concept in at least four different courses. Unfortunately, they often fail to realize it is the same business decision making tool being applied to several different problems. In Adventures in Entrepreneurship, break-even analysis is introduced as a tool and then applied to the different functional settings through the requirements of the business plan. This not only reinforces the integrative nature of the tool, it also reduces the instructional time the core business curriculum devotes to the topic. Other cross-functional topics and skills are presented in a similar fashion. Exhibit 4 conceptualizes this approach.

Exhibit 4

Common Content Unified Through Business Plan

\begin{tabular}{|c|c|}
\hline Course & Concept \\
\hline $\begin{array}{c}\text { Managerial } \\
\text { Accounting }\end{array}$ & $\begin{array}{c}\text { CVP Analysis } \\
\text { Operating Leverage }\end{array}$ \\
\hline $\begin{array}{c}\text { Fundamentals } \\
\text { of Finance }\end{array}$ & $\begin{array}{c}\text { Operating Leverage } \\
\text { Financial Leverage } \\
\text { Project Break-Even }\end{array}$ \\
\hline $\begin{array}{c}\text { Business } \\
\text { Decision } \\
\text { Making }\end{array}$ & $\begin{array}{c}\text { Labor vs Capital } \\
\text { Tradeoffs }\end{array}$ \\
\hline $\begin{array}{c}\text { Marketing } \\
\text { Principles }\end{array}$ & Product Break-Even \\
\hline
\end{tabular}

Obviously, not every introductory topic relates directly to the business plan. Nevertheless, these topics need to be covered in order for students to be prepared for upper level classes. A good example from finance might be the valuation of publicly held shares of stock. Here, the Finance professor might motivate a lecture by referring to the Initial Public Offering (IPO) process that was covered in a business plan lecture and then show students how their business might be valued by the public auction markets. Nevertheless, to help ensure that students are prepared for upper level classes, exams are comparable, in scope and depth, to those in the stand-alone core courses.

\subsection{From Business Plan To Implementation}

An important set of boundary conditions increase the likelihood that one of the business plans can be implemented successfully during the spring semester practicum. In order to leave time for closing the books, evaluating the business outcomes, and tying up loose ends, the business operations have to cease by the conclusion of 
spring break. Initial start-up capital is limited to $\$ 750$ and has to be repaid with interest. Start-up capital is provided by the Dean's office in the school of business, illustrating the administration's support for the program. The concept has to be simple enough for students to present detailed strategic and operational plans at the beginning of the second semester. The organizational plan must clearly define responsibilities and reporting mechanisms. It must address appropriate management, operational, marketing, finance, accounting, and international business concerns. The assessment plan must include individual and team criteria, including a peer evaluation system modeled on the Team Evaluation Form in Exhibit 3. The faculty team acts much like a board of directors. They are available for guidance and mentoring. They meet with the student teams on a regular basis in both the fall and spring. They approve the organizational and implementation plans and assess how well the organization functioned over the semester.

A post mortem assessment allows each student and student team to reflect on the successes and failures of their operations. There are two key components of the post mortem. First, students must complete their portions of the individual and team assessments as defined in the organizational plan. The assessment is expected to be an honest evaluation of how well the student and his/her team fulfilled the responsibilities, timetables, and quality standards established in the organizational and implementation plans. It answers the question: to what degree did you meet, fail to meet, or exceed your duties and responsibilities? The second component of the post-mortem is a written assessment of what the student would do differently.

\subsection{Faculty Selection}

Each year the instructional team has been made up of full time faculty members from each of the five business disciplines. Faculty are asked to make a three year commitment to the program. However, in any given year, no more than three of the five faculty members have previously taught in the program. As a whole, the faculty team has been committed to the model. However, not all of its members volunteered to teach in the program. Rather, faculty members have been asked by their respective department chairs to represent their departments.

\subsection{Student Selection}

Students apply for the program in the spring semester of their freshman year. The faculty team selects students for the program based on a variety of factors including a one-paragraph statement of interest (what will you contribute to the program, and how will the program contribute to your education), a faculty recommendation, fall semester GPA, and SAT scores. Faculty also try to select a diverse group of majors for the program. At this point in its development, the program is limited to a single section of 30 students.

\subsection{Program Summary}

Overall, the program is designed to achieve the following outcomes:

- $\quad$ Develop mastery of core concepts from each discipline

- $\quad$ Develop an understanding and appreciation of how functional areas work together

- Develop an ability to work effectively in teams

- $\quad$ Develop creativity, critical thinking, and planning skills

- $\quad$ Develop the ability to construct a persuasive business argument in the form of a business plan

- $\quad$ Launch and manage a campus-based, entrepreneurial venture

- $\quad$ Eliminate redundancies in the business core curriculum

In order to accomplish these outcomes, faculty meet weekly to coordinate topic coverage, assess student progress on the semester practicum, and discuss overall program management. Faculty also meet in the summer and the winter intersession for overall program planning. 


\section{Challenges And Solutions}

A key challenge has been properly estimating the complexity, time, and skill sets required to complete a business plan and implement a small campus-based business. Initially, all five instructors budgeted less class time to business plan issues than students found necessary. As a result, students were frustrated with the gap between the amount of class time devoted to, and faculty expectations of, the business plan. The problem was exacerbated by student confusion over whether to bring business plan questions to that day's classroom instructor or to the subject matter expert. This issue was addressed by assigning a faculty mentor to each business plan team. Also, the class adopted a common business plan template to guide the student teams (see Exhibit 2). This helped reduce anxiety over grading concerns. Finally, the entire class and the faculty reserved one hour of class time every other Friday to meet and discuss common issues and concerns about the business plans.

A continual challenge for the students is developing realistic business concepts that can be implemented within the constraints imposed by the program. One team originated a concept to sell a combination backpack cooler. They developed a workable product design, the test marketing was positive, and they found a willing supplier in Hawaii. Unfortunately, the production lead time was six months which pushed the launch date beyond the course constraints. Although the plan was very good in all aspects but one, it could not be implemented. Another difficult hurdle is convincing classmates that they will be able to actively participate in a product launch. For example, one student team developed a business plan for a web-based spring break information service. The concept was well developed and could have been implemented. Nevertheless, the class chose to pass on implementation because too many students felt that the job descriptions and opportunities were limited.

An ongoing concern is that most, if not all, of the business plans need extra help with financial and accounting issues. One team demonstrated their limited understanding of cost accounting by including oxygen as a production cost for an apparel product. Under review, the team acknowledged they created the entry because an oxygen product cost had appeared in one of the integrated cases.

Although the faculty and students agree that the actual launch of the student business is extremely rewarding, university support staff are not always prepared for the experience. A key issue is that support structures on campus, from physical plant to accounting, have difficulty treating the students as business people. For example, the campus reservation system has bumped student businesses from reserved venues "for more important events." The idea for a food cart to serve evening MBA students was overruled by the campus food service provider, despite the fact that the service provider does not stay open for evening MBA students. One year, on the first evening of business operations, a faculty mentor received a frantic phone call from the student business CEO:

Help! The grad student from the university accounting department has removed the cash card machine because he wants to go home and study for an exam. We now have no way to complete sales transactions.

One student summed it up well when she stated:

... no one ever seemed to figure out if we were a student club, a class, or a real business. We knew we wanted to be treated as a real business so it got extremely frustrating when we were treated as students.

Despite the integrative nature of the class and the efforts by the faculty to stress cross-functional themes, students sometimes fail to connect elements of their business plans to certain discipline-specific topics. The problem is particularly relevant for International Business. Most of the student plans are domestically oriented, and the International Business instructor has found it difficult to fully relate his material to the business plan. In one year, all plans had their international business components as an appendix, making it difficult to integrate these vital dimensions into the marketing, strategic, or financial projections of their proposed companies.

A pedagogical concern is that some students perceive as unimportant those topics that are not directly related to either the business plan or the practicum. From the student's perspective, the business plan and its implementation are the most important features of the course. Some topics, although not directly related to the business 
plan, are strongly emphasized by the faculty and receive corresponding weight in final grading. Nevertheless, students can become critical of course content they feel is irrelevant to their business plans or operations.

Recruiting faculty to participate in the program has also been challenging. Some faculty perceive Adventures in Entrepreneurship to be more complex, dynamic, and unpredictable than a conventional core class. Beyond the extra time required for team meetings and the support given to student entrepreneurs, teaching materials are inadequate. Discipline-specific texts cover subject matter from a principles perspective, without connections to entrepreneurship or business plan development. Introductory entrepreneurship texts cover the relationship of management, finance, accounting, marketing and international business to entrepreneurship, but fail to cover the discipline-specific topics in sufficient depth. In addition, the students' business issues may need to be addressed in classroom presentations that do not necessarily spring from a set of pre-determined lecture notes. The compromise reached in Adventures in Entrepreneurship is to utilize field specific principles textbooks supplemented by a business planning book. However, this approach means that each faculty member must develop mechanisms to bridge gaps between their discipline and entrepreneurship.

These types of problems are not unusual in team teaching models. Closs and Stank (1999) note similar challenges arising from faculty and departmental entrenchment, limited faculty expertise and knowledge of other disciplines, as well as difficulties in determining credit hours for teaching load purposes. Our experience suggests that additional resources are necessary to recruit faculty into the program. In some cases, subject matter experts may lack an entrepreneurship perspective and require assistance in developing this new perspective. Other faculty may require selective course releases to help ease into the extra demands of a team teaching environment. Finally, summer course development grants may help support faculty efforts to improve teaching materials.

\section{Ongoing Program Evaluation}

Students have ongoing opportunities to evaluate and influence program design and execution. At the end of each semester, students complete traditional faculty evaluations of each instructor, including both scale based and open ended questions. These evaluations allow faculty to compare student perceptions from Adventures in Entrepreneurship to their other classes. Approximately midway through the fall semester and at the start of the spring semester, faculty and students meet to discuss student concerns. Students anonymously write down and hand in three or four suggestions for improving the class. The entire class, including faculty, read through and discuss the suggestions. These "venting" sessions have resulted in the previously mentioned business plan mentor, several scheduling improvements, and better coordination of quizzes and tests. At the end of the spring semester, students participate in a focus group feedback session conducted by an outside faculty person. Students in the focus group sessions have expressed overwhelmingly positive views about their experiences in the program. The majority of students answered positively to the questions, "would you repeat this course," and, "would you recommend that other students take this class." In the last two years, two younger siblings have taken the course upon the recommendation of their older sibling!

The active learning elements appear to have many positive outcomes. Student attitudes and behaviors evolve in response to the challenges of planning and running a business. They appear to gain independence and confidence. It also seems clear that students' understanding of business problems extend well beyond lectures or textbooks. At the post-mortem, students continually reference what they could have and should have done to avoid problems they faced while operating the business. Students report that functional teams generally work well and lead to important "bonding" experiences. Students also comment that although the program is demanding they feel they come out ahead of their counterparts in the traditional stand-alone core courses. They feel they are seeing the "whole picture" and developing a better appreciation for the interrelationships among business disciplines. Phrases like, "I got to see how it all works together," are not at all uncommon. An interesting phenomenon is that student satisfaction increases significantly over the course of the year. In particular, spring program evaluations have been significantly higher. Focus group feedback sessions have also uncovered additional evidence that integration and understanding begin to gel in the spring semester. 


\section{Conclusion}

This paper presents a case study of an innovative approach to teaching core business concepts. The program challenges the traditional silo model by emphasizing cross-functional integration of functional topics. Integration is achieved by organizing and presenting content around the development and implementation of a campus based student business. Hence, the integrating vehicle is entrepreneurship. The program is built around two active learning elements: the development of a business plan and the implementation of a student business. We identify through interviews of students and faculty the key challenges and opportunities that remain. From the student and faculty feedback it appears obvious that while certain improvements need to made and institutional resources increased, the course offers a unique educational experience.

\section{References}

1. Aurand, T.W., DeMoranville, C., and Gordon, G.L. (Fall 2001). "Cross-Functional Business Programs: Critical Design and Development Considerations", Mid-American Journal of Business, Volume 16, 21-30.

2. Barber, C.S., Borin, N., Cerf, D.C., and Swartz, T.A. (2001). "The Role of Marketing in an Integrative Business Curriculum", Journal of Marketing Education, Volume 23, 240-248.

3. Barker, R.T., Gilbreath, G.H., and Stone, W.S. (1998). "The Interdisciplinary Needs of Organizations: Are New Employees Adequately Equipped?", The Journal of Management Development, Volume 17, 219.

4. Behrman, J.N. and Levin, R.J. (Jan.-Feb. 1984). “Are Business Schools Doing Their Job?”, Harvard Business Review 62 (1) 140-147.

5. Bradford, B. and Peck, M.(1997). "Achieving AECC Outcomes through the Seven Principles for Good Practice in Undergraduate Education”, Journal of Education for Business 72 (6): 364-368.

6. Closs, D. J. and Stank, T.P. (1999). "A Cross-Functional Curriculum for Supply Chain Education at Michigan State University", Journal of Business Logistics, Volume 20, 59-72.

7. DeMoranville, C., Aurand, T.W., and G.L. Gordan (2000). "The Delivery of an Undergraduate Crossfunctional, Business Principles Program: One University's Continuing Journey”, Marketing Education Review, 10(3): 29-41.

8. LeClair, D. (August 1998). "Economics of Organization and Management: An Integrative Course Proposal", Journal of Management Education, 22 (4).

9. Luse, D. W. (1999). "Incorporating Business Communication in an Integrative Business Seminar", Business Communication Quarterly, Volume 62, 96-100.

10. McKinney, E. (Oct 1998). "The One School Roomhouse: An Information and Learning Approach to Curriculum Integration", Journal of Management Education, 22 (5): 618-636.

11. Michaelsen, L.K. (1999). "Integrating the Core Business Curriculum: An Experience-Based Solution", Selections, Volume 15, 9-10.

12. O'Sullivan, D.W. and Cooper, C.L. (May 2003). "Evaluating Active Learning: A New Initiative for a General Chemistry Curriculum", Journal of College Science Teaching, Vol. 32, Number 7, 448-452.

13. Pharr, S.W., Morris, J.S. and Stover, D. (1998). "The execution and evaluation of an integrated business common core curriculum", The Journal of General Education, Volume 47, 166-182.

14. Porter, L. and L. E. McKibbin (1998) Management education and development: Drift or thrust into the $21^{\text {st }}$ century? New York: McGraw-Hill.

15. Quinnipiac University School of Business Committee Report (2000), Unpublished Manuscript

16. Weinstein, C. (Fall 1996). "Learning how to learn: An essential skill for the $21^{\text {st }}$ century", The Educational Record, Vol. 77, 48-51. 